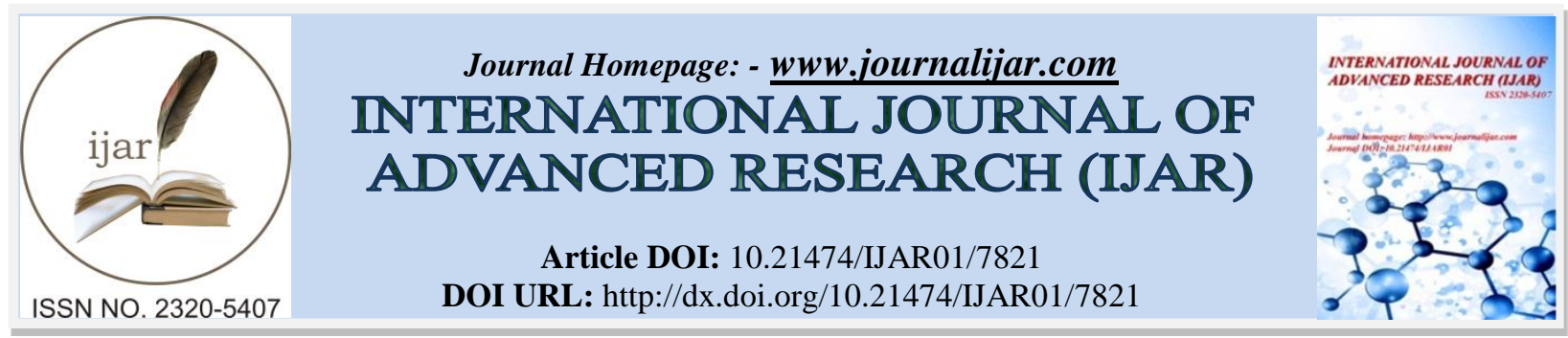

RESEARCH ARTICLE

\title{
A STUDY THE CONTRIBUTION OF MICRO FINANCE ON POVERTY ALLEVIATION IN BATTICALOA DISTRICT OF SRI LANKA.
}

Mr V. Navirathan.

Senior Asst. Registrar Eastern University, Sri Lanka.

\section{Manuscript Info}

Manuscript History

Received: 6 August 2018

Final Accepted: 8 September 2018

Published: October 2018

\section{Keywords:}

Micro finance, Poverty alleviation,

Economic Development.

\section{Abstract}

This study aimed at assessing the contribution of micro finance to poverty reduction in Batticaloa District of Sri Lanka. Specifically, the study had the aim of assessing the contribution of micro finance to the social development of entrepreneurs, to determine the impact of microfinance to poverty reduction and also finding out challenges facing entrepreneurs in the credit acquisition from micro finance. The study was carried out in Batticaloa District of Sri Lanka.

The study employed descriptive statistical approach to describe the findings from selected case studies, with the aim on describe the data and characteristics about what is being studied. The target population was the Entrepreneurs who acquire loans and other financial services from various financial institutions such as Samurdhi Bank, BRAC Sri Lanka, Navagiraka and Commercial Banks. These were interviewed by asking them to answer both closed and open ended questions. The sample comprised a total of 120 entrepreneurs(Households).

The study findings revealed that there is positive contribution of microfinance to the social development, in which there is better access to health, education and basic services and greater social respect. The contribution of education level and entrepreneurial skills has positive impact to poverty reduction. From the finding obtained it has been found that micro finance has a positive impact to poverty reduction in which there is increase in income, better living conditions and better access to basic needs. Lastly study found that challenges facing entrepreneurs are short time for loan repayment, low amount offered by MFIs, expensive collaterals and high interest rates.

It is therefore recommended that government and other stakeholders should work together to make sure that, time given to repay loans is increased, to increase the amount which is borrowed, the collateral for loans should be that which most Entrepreneurs can afford and thirdly the interest rates should be lowered.

Therefore, the major purpose of this study are analysis contribution of micro finance on poverty alleviation and lessons learn to future economic development.

Copy Right, IJAR, 2018,. All rights reserved. 


\section{Introduction:- \\ Background of the Study}

Microfinance institutions (MFIs) have been established in various countries in the world as a means to provide banking services to the poor and low income people. The development of MFIs can be attributed to efforts made by Muhammad Yunus an economics Professor, who began an experimental research project in Bangladesh during the 1970s. Yunus initiated a micro credit programme and founded the Grameen Bank in Bangladesh as a bank that delivers services to the poor people (Katsushi,Thankom \&Samuel, 2010). MFIs play a significant role on poverty reduction throughout the world. They provide credit and insurance facilities to enable the poor to smooth their consumption, enhance their income earning capacity and enjoy an improved quality of life (Cuevas, 1992). It has proved its value in many countries as a weapon against poverty and poor life.

To enhance international development, the United Nations Organization (UNO) announced the millennium development goals, aimed to eradicate poverty by 2015. In this regard, microfinance is the form of financial development that has its primary aim to alleviate the poverty. Governments, donors and NGOs around the world responded enthusiastically with plans and promised to work together towards the realization of these goals. In the recognition of microfinance, the UNO celebrated the year 2005 as a year of micro-credit, as a result this financing instrument is perceived worldwide as a very effective mean against hunger and poverty, mainly in developing countries.

Sri Lanka has a long history in having a rudimentary system of microfinance. 'Cheetu' in Sri Lanka, operating at least since the early 20th century, is an informal but an effective way of savings and capital accumulation, and therefore, functions as a basic method of microfinance for the poor. The microfinance sector in Sri Lanka has grown into a diverse range of institutions and products and represent a significant method of financial inclusion, and empowerment for the low income and poor segments of the society.

Sri Lanka also faces the worst out comes of poverty Since long time ago. Sri Lanka has among the lowest extreme poverty rates among countries in the region, as 1.8 percent of the population were estimated to be extremely poor in 2013. However, living standards remain low, as nearly 45 percent of the population lived on less than $\$ 5$ per day in 2013.

Sri Lanka also applied microfinance as a poverty alleviation tool. Various institutions providing microfinance in Sri Lanka, such as licensed banks, licensed finance companies, co-operative rural banks, thrift and credit co-operatives societies, Samurdhi banks and other community-based organizations, microfinance companies, non-governmental organizations that engage in microfinance business. Some of these institutions are regulated under different authorities. Licensed banks and licensed finance companies are regulated by the Central Bank. Co-operative rural banks and thrift and credit co-operatives societies are regulated by the Department of Cooperative Development, with Samurdhi Banks being regulated by the Department of Samurdhi Development. However, there were many microfinance providers that are not under the purview of a regulatory authority.

There are numbers of Microfinance Institutions have giving the loans for development of quality of life of the people. Unfortunately, the poverty is still remaining in the District. Therefore this study try to find the relationship between the Micro finance and Poverty of the Batticaloa District.

\section{Problem Statement}

Thirty years of demolished the people's economic in various ways. It was ended in 2009. Many microfinances institutions came forward to help the people to uplift of their standard of living. In thisKhandker $(2001,2003)$ found that the positive impact of micro finance on the poverty has been identified with per capta income, per capta expenditure and over all wellbeing of the society in Bangladesh.And also, some researchers also positively supported (Zaid, 2008; Dunford, 2006; Pitamber, 2003; Amaha, 2002). Whilst, microfinance does not address the economic problem of the poverty. The scholars further claim that if address at all, either it benefits the middle poor or it help the poor to keep their soul in their body (Cowen \&Boundreaux, 2009; Kondo, Orbeta, Dingcong\&Infantad2008; Katsushi, Imai\& Arun, 2006; Morduch, 2005; Schreiner, 2002) are some behind this proposition. Hence often claim that microfinance lifts people out of poverty, but the evidence is mixed. The limited studies in this topic has been focused narrowly on microfinance and poverty alleviation. But this study involves in poverty alleviation in terms of income poverty and multi-dimensional poverty. Therefore, this study tries to investigate whether the microfinance really alleviate poverty in Batticaloa area? 


\section{Research questions}

The specific research questions of this study are:

1. What is the level of microfinance among the beneficiaries of micro finance institutions in Batticaloa area?

2. What is the level of poverty indicators among the beneficiaries of micro finance institutions in Batticaloa area?

3. What is the impact of microfinance on poverty indicators among the beneficiaries of micro finance institutions in Batticaloa area?

\section{Research Objectives}

The specific research questions of this study are:

1. To assess the level of microfinance among the beneficiaries of micro finance institutions in Batticaloa area.

2. To assess the level of poverty indicators among the beneficiaries of micro finance institutions in Batticaloa area.

3. To evaluate the impact of microfinance on poverty indicators among the beneficiaries of micro finance institutions in Batticaloa area.

\section{Significant of study}

The research is important for the continuous research about the microfinance and poverty alleviation. This should be carry out to find the success of the microfinance and its objective in Batticaloa area. The significant amount of people were get positive outcome because recommendations can be suggestions to implement their new business strategy if any new MFIs to be start in Batticaloa area. This research will be provided a base article in future for the upcoming research papers regarding poverty researches.

\section{Scope of the Study}

This study has the scope of investigating the impact of microfinance on poverty alleviation. In order to conduct this research, Batticaloa District selected. This study has used open-ended questionnaire for collecting primary data from 120 samples which were selected the beneficiaries of some selected microfinance institutions in Batticaloa District. The study understands that these analyses are merely sufficient to explore the relationship of study variables and to meet the objectives.

\section{Literature Review \\ The Poverty}

Poverty is described as the situation that emanates from lack of necessary capabilities and entitlements to satisfy human basic needs. This situation limits a person from acquiring security and assets, or from having power for decision-making (Chambers, 1983). About one -fifth of the world's population is afflicted by poverty. Poverty can always exist in society where some or all of its members fail to attain a certain level of well-being considered by that society as a reasonable minimum standard of living (Bagachwa, 1994).

Poverty is not only a state of existence but also a process with many dimensions and complexities. Usually it is characterized by deprivation, vulnerability (high risk and low capacity to cope) and powerlessness (Lipton $\&$ Ravallion, 1995). These characteristics impair people's sense of well-being.

In order to understand poverty, it is essential to examine the economic and social context, including the state, markets, communities and household (Sen, 1999). Poverty differences cut across gender, ethnicity, age, residence (rural versus urban) and income sources. In households, children and women often suffer more than men while in the community, the rural poor suffer more than the urban ones. In order to understand poverty relations in rural areas and its effects on different groups, the assets owned by poor and those, which they have access to, should be examined for their links to economy (Jere, 1993).

\section{Rural Financial Institutions Contribution to Poverty Reduction}

At a national level an adequate level of food production is a necessary condition for food security but it is not sufficient to ensure access to food for all people at all times. Access to food is governed by income and purchasing power. This exists for strategies at household levels to cope with food insecurity. Income generation and diversification, savings and dissaving (in kind and in cash), borrowing and inter house hold gift exchange. The effectiveness of rural MFIs in reducing poverty can be assessed through three criteria. Coverage of the poor and financial needs fair access for disadvantaged group e.g. women and landless, financial viability and long-run sustainability (Zeller, Schrieder, Braun\&Heidhues,1996) a Research conducted by India's Integrated Rural Development (IRDP) in India, showed great success in increasing the income of large numbers to disadvantaged 
households. Hossain (1988) found out that more than 90\% of the Grameen Bank (GB) clientele enjoys a living standard that is higher than prior to participation in the Grameen Bank. In the Grameen Bank members had a 40\% higher income than comparable population groups in non-Grameen Bank villages (Hulme,2000).

Another financial innovation practiced in Zimbabwe by Savings Foundation of Zimbabwe found out collective savings mobilization and agricultural productivity of its clientele. A part of the group members' accumulated savings is converted into its productive inputs that are bulk-ordered through the foundation. About $97 \%$ of the group members are poor rural women. Under the foundation they can acquire new skills, improved housing and become financially more independent (Berger, 1989). Improved agriculture productivity and financial liquidity is crucial to enhance food security. Other studies conducted in Mali, Gambia and ACCION international in Latin America had demonstrated the potential contribution of the RFIs in raising the productivity and income of the poor in the rural areas.

\section{Microfinance}

Microfinance is a form of financial development that has primarily focused on alleviating poverty through providing financial services to the poor. Most people think of microfinance, if at all, as being about micro-credit i.e. lending small amounts of money to the poor. Microfinance is not only this, but it also has a broader perspective which also includes insurance, transactional services, and importantly, savings.

According to James Roth, "Microfinance is a bit of a catch all-term. Very broadly, it refers to the provision of financial products targeted at low-income groups. These financial services include credit, savings and insurance products. A series of neologisms has emerged from the provision of these services, name micro-credit, microsavings and micro-insurance".

The Canadian International Development Agency (CIDA) defines microfinance as, "the provision of a broad range of financial services to poor, low income households and micro-enterprises usually lacking access to formal financial institutions"

\section{Characteristics of Microfinance}

Microfinance gives access to financial and non-financial services to low-income people, who wish to access money for starting or developing an income generation activity. The individual loans and savings of the poor clients are small. Microfinance came into being from the appreciation that micro-entrepreneurs and some poorer clients can be 'bankable', that is, they can repay, both the principal and interest, on time and also make savings, provided financial services are tailored to suit their needs. Microfinance as a discipline has created financial products and services that together have enabled low-income people to become clients of a banking intermediary. The characteristics of microfinance products include:

1. Little amounts of loans and savings.

2. Short- terms loan (usually up to the term of one year).

3. Payment schedules attribute frequent installments (or frequent deposits).

4. Installments made up from both principal and interest, which amortized in course of time.

5. Higher interest rates on credit (higher than commercial bank rates but lower than loan-shark rates), which reflect the labor-intensive work associated with making small loans and allowing the microfinance intermediary to become sustainable over time.

6. Easy entrance to the microfinance intermediary saves the time and money of the client and permits the intermediary to have a better idea about the clients' financial and social status.

7. Application procedures are simple.

8. Short processing periods (between the completion of the application and the disbursement of the loan).

9. The clients who pay on time become eligible for repeat loans with higher amounts.

10. The use of tapered interest rates (decreasing interest rates over several loan cycles) as an incentive to repay on time. Large size loans are less costly to the MFI, so some lenders provide large size loans on relatively lower rates.

11. No collateral is required contrary to formal banking practices. Instead of collateral, microfinance intermediaries use alternative methods, like, the assessments of clients' repayment potential by running cash flow analyses, which is based on the stream of cash flows, generated by the activities for which loans are taken. 


\section{Methodology of Microfinance}

Majority of the MFIs offer and provide credit on a solidarity-group lending basis without collateral. There is also a range of other methodologies that MFIs follow. Some MFIs start with one methodology and later on move or diversify to another methodology so that they do not exclude certain socio-economic categories of clients. So it becomes important to have a basic understanding of methodologies and activity of MFIs.

\section{Group Lending}

Group based lending is one of the most novel approaches of lending small amounts of money to a large number of clients who cannot offer collateral. The size of the group can vary, but most groups have between four to eight members. The group self-selects its members before acquiring a loan. Loans are granted to selected member(s) of the group first and then to the rest of the members. Most MFIs require a percentage of the loan that is supposed to be saved in advance, which points out the ability to make regular payments and serve as collateral. Group members are jointly accountable for the repayment of each other's loans and usually meet weekly to collect repayments. To ensure repayment, peer pressure and joint liability works very well. The entire group were disqualified and will not be eligible for further loans, even if one member of the group becomes a defaulter. The creditworthiness of the borrower is therefore determined by the members rather than by the MFI.

One of the best-known institutions for lending and savings money, in Bangladesh, is the Grameen Bank. Grameen Bank mainly targets women (98\% of their clients are women) on the basis that women repay their loans better than men and due to the oppression, they need more favor. It is believed that loans expanded to women benefit all the household members with improved level of food intake, health, and education. Average loans range from US\$120 to US\$200 for a period of 3-12 months. The loan amount varies fromcountry to country. Average loan amounts tend to be higher ( $\$ 500$ or more) in countries in transition of adapting to this system.

On one hand, the group formation guides to lower transaction costs for the MFIs, but on the other hand there are social costs related with this process. These social costs can be a negative restraint to group borrowing and joint liability approaches, and include coercive peer pressure, loss of faith and the likelihood that the poorest and most vulnerable will remain excluded or further stigmatized. Such social costs are higher in some societies than in others, depending upon underlying social relations (which influence the ease/difficulty of group formation) and the distances that people must travel to participate in-group activities. In rural areas, these costs can be higher.

\section{Individual Lending}

Unlike MFIs, there are very few conventional financial institutions which provide individual loans to low-income people because poorer clients are considered higher risk clients due to their lack of collateral, plus the laborintensive nature of the credits and hence the lack of profitability of small-credits. BASIC BANK (Bangladesh), Bank Rakyat Indonesia (BRI) in Indonesia, ADEMI in the Dominican Republic and are some examples of successful lenders to poor clients. However, BRI does request collateral and a loan co-signer, while ADEMI and BASIC Bank will take the best collateral it can.

\section{Credit Unions}

According to Murray and Boros (2002)Credit unions are the organizations that are formed on the basis of financial relation of savings and loans between its members. They accumulate savings from its members and provide shortterm credit to the needed members. The demand for loans in general exceeds the supply of savings. In most rural areas credit unions are still the solitary source of deposit and credit services, besides the informal financial market. Because credit unions have social as well as commercial objectives, they may have a key role toplay in offering propoor financial services. It has been observed that some women have not benefited much from the credit unions because the level of savings required is too high.

\section{Village Banking}

According to Murray and Boros (2002)Village banking is a kind of financial services model that assists poor communities to establish their own credit and saving associations, or village banks. Village bank provides noncollateralized loans to its members and a place to invest savings and promote social solidarity. The sponsoring agency provides loan for the village banks and village banks in turn provide individual loans to its members. Peer pressure and peer support among the members are considered as the bank guarantees of these loans, to ensure repayment where small working capital is repaid every four to six months by its borrowers. Borrowers start with a very small loan and gradually they establish loan ceiling. Loan sizes depend on the amount which borrower has 
saved. Member's savings are kept for the purpose of lending or investing to increase the resource base of the bank. Commercial standards are applied to determine interest rates and fees.

\section{Self Help Groups/Associations}

According to Murray and Boros (2002)Rotating Savings and Credit Associations (ROSCAs) exist in several parts of the world but recognized under different names, like as Tontines and Susus. They are known to befemale dominated organizations that save small amount of money and members can borrow from common pool on a rotating basis. These types of organizations or self-help groups, have sometimes been used by MFI for group lending among the members.

\section{Micro Credit Initiatives for Equitable and Sustainable Development}

The concept of micro credit extension of small amounts of collateral -fee institutional loan jointly liable poor group members for their self-employment and income generation. Over the last two decades the Grameen Bank has pioneered a credit delivery system in rural Bangladesh bringing the banking service to poor villages and focusing primarily on women. The cumulative investment of the Grameen bank in the rural Bangladesh is more than one billion US dollars disbursed among its 2.02 million members, 94\% of whom are women (Grameen Bank, 1994).

In 1980s the programmatic success of the micro credit such as Grameen Bank among in rural Bangladesh became a demonstration of a successful equitable and sustainable development initiative. The programmatic success and the accreditation of this success by the large number of impact and academic studies (Chandker 1987; Hossain 1988; Rahman 1986;Mizan 1994; Shehabuddin, 1992) have contributed to the spread of micro credit concept worldwide.

The approach used by Grameen Bank of lending poor women has attracted international interest and made the micro credit approach as a new paradigm for thinking about the economic growth (Morduch, 1997). Now there is almost a global consensus that micro lending to the poor that focuses on the achievement of equitable and sustainable gain is the key element for the 21 st century's economy and social development. Currently most bilateral development agencies incorporate micro credit into their development projects and are keen to push other multi-sectoral social development- oriented non-government organizations into the function of credit delivery (Wood \& Sharif, 1997).

\section{The Importance of Rural Financial System to Economic Development}

Financial sector development promotes economic growth and is also important to reduce poverty (DFID, 2004a \& 2004b). DemirgucKunt and Levine (2004) conducted a study in over 150 countries and noted that a well-functioning financial system is critical to long-run growth. Empirical evidence from traditional studies confirms the strong, positive link between the national savings (aggregate income less total expenditure) and economic growth (World Bank, 2004). Correlation between the levels of financial savings (Savings held in liquid forms in the formal financial sector) and growth is even stronger (Fry, 1995). Savings are more important as they allow households to maintain precautionary balances against shocks. Households can also build up cash collateral and track record savings will allow them easier accessible deposit facilities and as a consequence, savings are held as cash or assets (e.g. livestock and building materials). Such savings are harder to mobilize and do not increase availability of loanable funds. Rural entrepreneurs therefore find it difficult to access funds and have to rely largely on self-financing when they want to invest.

Financial institutions should ideally provide low cost and accessible channels for transfer of remittances (e.g. migrant wages), which are crucial to the copping strategies of many rural households (Orozco, 2003). Rural finance plays a crucial role in household strategies to reduce vulnerability. It assists the poor to smooth the consumption and to build up assets greater than the value of liability (Gonzales-Vega, 2003). This is particularly important for the rural poor, since agricultural incomes and health fluctuate widely and could destabilise consumption if the households have no savings or credit to fall back on (IFAD, 2003; World Bank 2004). Furthermore, rural households lack sufficient access to formal insurance, relying instead primarily on informal safety nets. Improved access to insurance could reduce the enterprise and household risks and make investment in rural economy more attractive contributing to growth and poverty reduction (Von Pischke, 2003).

\section{Empirical Evidence of Micro Finance as Solution to Poverty}

Poor people often have little access to credit and savings service even if they are able to save. They can't provide collateral for credit and are therefore often not even served by informal financial markets. One answer to the problem has been the promotion of the micro finance schemes. Micro finance both serves the savings (consumption and smoothening) and investment objectives of poor borrowers (Johnson \&Rogaly, 1997). 
Many of these schemes have been successful in terms of both loan recovery rates and increasing output (Hulme\& Mosley, 1998), while others have been less successful and often require continuation of government subsidy (World Bank 2000). The Grameen Bank in Bangladesh is usually presented as a model scheme in particular because of its pioneering peer-monitoring approach to overcome the moral hazards problem and because of its emphasize on lending to women, a feature which has been mulated by other scheme (Goetz \& Gupta, 1996). These schemes and indeed the other micro finance approach have been subject to critical scrutiny. While micro credit schemes have helped to empower women there is evidence that women have often been forced to borrow on behalf of men (Goetz \& Gupta 1996).

A study of 253 loans to women from micro finance agencies in Bangladesh revealed that almost $63 \%$ of the women borrowers had partial or very limited or no control over their loans (Goetz \& Gupta 1996). Micro finance schemes then have problem in getting the men to repay loans for which the women are responsible.

This study raises issues not only about gender but also about the wider question of different individual behaviours within the household and the problems of treating the households limits of the micro finance appear to be recognized by the World Bank in its 2001/ 2002 report and in particular the lack of valuable collateral.

Micro credit risk is covered in micro finance schemes by giving participants the ability to establish a reputation for reliability in the repayment of loans. However, it takes time to establish such reputation and usually means that although the micro finance schemes will lend again, other sources of the credit may still be closed off.

Indeed, the World Bank report addresses this issues of proposing movable properly as collateral, by establishing registers of secured interests so that lenders can ensure that collaterals have been advanced against loans and by establishing credit registers run by credit reporting agencies (World Bank 2001).

\section{Research Methodology:-}

\section{Study Population}

In this study, the target population comprised of beneficiaries of MFIs in Batticaloa area. The beneficiaries of MFIs are commonly poor and low income households. The microfinance institutions are mainly depending on them.

\section{Sampling Technique}

In case of this study, convenience sampling procedure is used. Convenience sampling is a statistical method of drawing representative data by selecting people because of the ease of their volunteering selecting units because their availability or easy access. The advantage of this type of sampling are availability and the quickness with which data can be gathered.

\section{Sampling Size}

Sample is a sub group of the population selected for the participation in the study. For the purpose of data collection, the sample covers the beneficiaries of MFIs, who are residents in Batticaloa area. The Microfinance beneficiaries are 21567 in Batticaloa District. Therefore, this study conveniently selected 120 beneficiaries of MFIs in Batticaloa area.

\section{Methods of Data Collection}

It refers to what were data used to carry out this research study and how the data were collected. There were two types of data used for the research study such as primary data and secondary data.

\section{Primary Data}

Primary data refer to Information obtained firsthand by the researcher on the variables of interest for the specific purpose of the study. In this research data collected for investigate particular research problem. An empirical investigation is conducted through the development of structured questionnaire that filled up by 120 beneficiaries of MFIs in Batticaloa area.

\section{Secondary Data}

There are several sources of secondary data, including various books, Central Bank Reports, academic journals, and articles of different kinds in order to gain a perspective (Sekaran, 2006). The theoretical foundation of the study was 
based on various sources such as journal articles, text books, magazines and published papers, newspapers, web sites and records of the relevant institutions.

\section{Methods of Data Analysis and Data Evaluation}

According to the characteristics of gathered data, it was analyzed. The quantitative data analysis function is facilitated by statistical package for social science (SPSS 22.0 version).

\section{Hypothesis Test}

Testing of hypothesis is one of the most important aspects of the theory of decision making. This research tests three hypotheses by using correlation \& regression. A hypothesis is a statement that test one or two measurable variables. Hypothesis testing is the strategy for deciding whether a sample data offer such a support for a hypothesis, that generalization can be made. Thus, hypothesis testing enables making probability statement about population parameter.

H1: There is significant relationship between Microfinance and Income.

H2: There is significant relationship between Microfinance and Employment.

H3: There is significant relationship between Microfinance and Household saving.

\section{Results and Discussion: -}

To explore and evaluate the main objective, regression analysis is used to measure in the study. Here Microfinance is independent variable and Poverty indicators are dependent variables. The study conducted a simple linear regression analysis to know the strength of relationship between the independent variable of Micro finance and dependent variables of Poverty indicators.

This study has three hypotheses and all the null hypothesis was rejected. Those hypotheses are; significant relationship between Microfinance and Income (H1), significant relationship between Microfinance and Employment (H2), significant relationship between Microfinance and Household saving (H3), These poverty indicators have strong positive relationship with Microfinance.

\section{Impact of Microfinance on Income among Beneficiaries of MFIs in Batticaloa Area}

Correlation analysis explained strong positive relationship between Microfinance and Income. Microfinance and income have the coefficient of correlation is 0.883 , Micro finance explained $78.1 \%$ of variance in income. And also the significant value is 0.000 , Hence, the significant value is lower than 0.05 .

The result of analysis has indicated that significant strong positive relationship between Microfinance and Income. Thus, the result provides the support to accept the first hypothesis (H1) of the study.

Coefficient of $b$ value of Microfinance is 1.111. Its means if Microfinance increased by one point Income will increased by 1.111. Hence, the positive impact of Microfinance on Income. When the satisfaction level of Microfinance increases, the satisfaction level of Income also increases.

\section{Impact of Microfinance on Employment among Beneficiaries of MFIs in Batticaloa Area}

Correlation analysis explained strong positive relationship between Microfinance and Employment. Microfinance and Employment have the coefficient of correlation is 0.820, Microfinance explained $67.2 \%$ of variance in Employment. And it has the significant value is 0.000 , Hence, the significant value is lower than 0.05 .

The result of analysis has indicated that significant strong positive relationship between Microfinance and Employment. Thus, the result provides the support to accept the second hypothesis (H2) of the study.

The coefficient of $\mathrm{b}$ value of Microfinance is 1.130. Its means if Microfinance increased by one point Employment will increased by 1.130. Hence, the positive impact of Microfinance on Employment. When the satisfaction level of Microfinance increases, the satisfaction level of Employment also increases.

This research paper also found that strong positive correlation and if satisfaction level of Microfinance increases, the beneficiaries' satisfaction level of Employment will be increased. 


\section{Impact of Microfinance on Household saving among Beneficiaries of MFIs in Batticaloa Area} Correlation analysis explained strong positive relationship between Microfinance and Household saving. Microfinance and Household saving have the coefficient of correlation is 0.753 , Microfinance explained $56.7 \%$ of variance in Household saving. And it has the significant value is 0.000 , Hence, the significant value is lower than 0.05 .

The result of analysis has indicated that significant strong positive relationship between Microfinance and Household saving. Thus, the result provides the support to accept the third hypothesis (H3) of the study.

The coefficient of $b$ value of Microfinance is 0.839 . Its means if Microfinance increased by one-point Household saving will increased by 0.839 . Hence, the positive impact of Microfinance on Household saving. When the satisfaction level of Microfinance increases, the satisfaction level of Household saving also increases.

This research paper also found that strong positive correlation and if satisfaction level of Microfinance increases, the beneficiaries' satisfaction level of household saving will be increased.

\section{Conclusions and Recommendations: -}

Finally, this study found that low level of satisfaction in Microfinance and low level of satisfaction in poverty indicators among the MFIs beneficiaries in Batticaloa area. The correlation analysis and simple regression analysis reveals strong positive relationship between Microfinance and poverty indicators. This reveals that low level of performance of Microfinance institutions lead to low level of satisfaction in poverty indicators. When the poverty indicators are in low level of satisfaction or improvement we can say there is no poverty alleviation. Hence, it produces the result that the Microfinance does not really alleviate poverty among the MFIs beneficiaries in Batticaloa area.

The study mainly focuses on the poverty alleviation of Microfinance. This study gives an idea how the Microfinance institutions performance in Batticaloa area and the MFIs beneficiaries in Batticaloa area attitude towards microfinance was revealed. The Microfinance institution and its beneficiaries' corporation is low in Batticaloa area. That is why year of 2017/18 there were many suicide and suicide attempt were performed.

This could be happened because both parties Microfinance and MFIs beneficiaries in Batticaloa. The Microfinance institutions have not performed their customer capable analysis and other analysis which is important to archive the purpose of the Microfinance. And the MFIs beneficiaries also have negative attitude of Microfinance. The MFIs beneficiaries' purpose of the loan should be satisfied.

The poverty measure cannot be improved unless the two parties of Microfinance rectify their mistakes. If the Poverty measure improved only poverty can be alleviated by the Microfinance. The poverty indicators are very strongly connected with Microfinance activities improvement. In future the Microfinance Improvement will lead to poverty alleviation in Batticaloa area.

The Microfinance institution should encourage Microfinance improvement, Microfinance Improvement in the sense, the improvement in planning stage of Microfinance activities, and execute stage of Microfinance activities in terms of Customer capable analysis and training. The internal audit system should monitor the beneficiary's usage of the loan. It could help improve the satisfaction level of Microfinance. This will lead to poverty alleviation by the Microfinance.

The Microfinance institutions should focus on training and micro insurance. It could be help to prevent the beneficiaries' entrepreneurship or self-employment. Hence, the fund will not be sunk on the crisis or bankrupt of the investment. It will lead to increase level of satisfaction of Microfinance through that satisfaction level of poverty indicators will be increased. Hence, Microfinance can really alleviate the poverty.

The Microfinance institution can be initiated commodity loan. This loan allows the materials of beneficiaries' entrepreneurships. For example, the farmer can be demand seeds, fertilizer, other services from the Microfinance company the company can arrange the demanded items. Or for the tailor the microfinance only gives the awing machine and the raw materials. Then the project is available for the long term. The return of the project ensures that 
the beneficiaries long term survival. That will lead to increase in satisfaction level of poverty indicators. Through that microfinance archive poverty alleviation.

The MFIs beneficiaries should focus on the usage of the loan. The Microfinance institution encourage the financial services to empowerment of the life with self-employment and entrepreneurships. But the motive of usage of the financial differ from the actual purpose. It should be eliminated from the beneficiaries' point. The amount of financial services should invest in long term survival of the beneficiaries. MFIs beneficiaries in Batticaloa area have used the financial services for the consumption purpose (Eg: purchase High end of Television, Stereo type Home theatres etc.). These kinds of practices will not lead to poverty alleviation. Hence, For the poverty alleviation the MFIs beneficiaries should invest the financial services in long term survival. It could help to improve the satisfaction level of poverty indicators and it lead to poverty alleviation.

\section{References:-}

1. Alailima, P., 2007. The Conventional Approaches: An Overview of Poverty in Sri Lanka in Fresh Perspectives: Exploring Alternative Dimensions of Poverty in Sri Lanka (eds.)

2. Amaha, W., (2002). "Challenges in Rural Development and Poverty Alleviation in Eastern and Southern Africa": The Role of Civil Society and Development Institutions.

3. Arifujjaman Khan, M., \&AnisurRahaman, M. (2007). Impact of Micro finance on Living Standards, Empowerment and Poverty Allevation of Poor People: A Case Study on Microfinance in the Chittagong District of Bangladesh(Doctoral dissertation, Thesis Master. Umea School of Busines. Bangladesh).

4. Armendgriz de Aghion, B. and J. Morduch (2005). The Economics of Microfinance. MIT Press: Cambridge, MA.

5. Armstrong, J. S., \& Dakin, S. (1989). Predicting job performance: A comparison of expert opinion and research findings. 